\title{
STATUS KEBERSIHAN MULUT DAN STATUS KARIES GIGI MAHASISWA PENGGUNA ALAT ORTODONTIK CEKAT
}

\author{
${ }^{1}$ Stany Cecilia Mantiri \\ ${ }^{2}$ Vonny N. S. Wowor \\ ${ }^{3}$ P. S. Anindita
}

\author{
${ }^{1}$ Kandidat skripsi Program Studi Kedokteran Gigi Fakultas Kedokteran \\ Universitas Sam Ratulangi Manado \\ ${ }^{2}$ Bagian Ilmu Kesehatan Gigi Masyarakat Program Studi Kedokteran Gigi \\ Fakultas Kedokteran Universitas Sam Ratulangi Manado \\ ${ }^{3}$ Bagian Ortodonsia Program Studi Kedokteran Gigi Fakultas Kedokteran \\ Universitas Sam Ratulangi Manado \\ Email: juztcecill@gmail.com
}

\begin{abstract}
Fixed orthodontic appliance are now widely used in society, but people often do not realize the risks of using this appliance such as oral hygiene and caries problem. The design of this appliance is more difficult to clean than removable orthodontic appliance, so that patient is more difficult to maintain oral hygiene. Poor oral hygiene can also cause caries. The purpose of this study is to obtain a description of the oral hygiene status and caries status of dental student using fixed orthodontic appliance in Faculty of Dentistry, Sam Ratulangi University Manado. Oral hygiene examination is using Patient Hygiene Performance (PHP) Index and caries examination is using Decay Missing Filling Teeth (DMF-T) index. This study is descriptive study. The population are all dental student using fixed orthodontic appliance in Faculty of Dentistry, Sam Ratulangi University Manado. Total sample is 38 people and the data taking with total sampling method. The distribution of oral hygiene showed that 34 people had a good oral hygiene (89.47\%), 4 people had a fair oral hygiene (10.53\%) and there were no respondents with bad oral hygiene. Distribution of dental caries indicates the average of DMF-T number was 0.631 and by category of WHO, included in the very low category.
\end{abstract}

Keywords: fixed orthodontic appliance, oral hygiene status, caries status.

\begin{abstract}
Abstrak: Alat ortodontik cekat saat ini sudah banyak digunakan di masyarakat, namun masyarakat sering tidak menyadari risiko penggunaan alat ortodontik cekat seperti masalah kebersihan mulut dan karies. Alat ortodontik cekat memiliki desain yang lebih sulit untuk dibersihkan dibandingkan dengan alat ortodontik lepasan, sehingga pengguna alat ortodontik cekat lebih sulit untuk memelihara kebersihan mulut selama perawatan. Kebersihan mulut yang buruk dapat menyebabkan karies selama perawatan. Tujuan dari penelitian ini yaitu memperoleh gambaran status kebersihan mulut dan status karies mahasiswa pengguna alat ortodontik cekat di Program Studi Kedokteran Gigi Fakultas Kedokteran Universitas Sam Ratulangi Manado. Status kebersihan mulut diperoleh dengan pemeriksaan menggunakan Patient Hygiene Performance (PHP) Index dan status karies diperoleh dengan pemeriksaan menggunakan indeks Decay Missing Filling Teeth (DMF-T). Penelitian ini merupakan penelitian deksriptif. Populasi penelitian yaitu semua mahasiswa pengguna alat ortodontik cekat di Program Studi Kedokteran Gigi Fakultas Kedokteran Universitas Sam Ratulangi Manado. Sampel berjumlah 38 orang dan pengambilan sampel dilakukan dengan metode total sampling. Hasil penelitian tentang kebersihan mulut menunjukkan 34 orang memiliki kebersihan mulut yang baik (89,47\%), 4 orang memiliki kebersihan mulut sedang (10,53\%) dan tidak terdapat responden yang memiliki kebersihan mulut yang buruk. Status karies gigi menunjukkan ratarata jumlah DMF-T ialah 0,631 dan menurut kategori indeks DMF-T dari WHO termasuk pada kategori sangat rendah.
\end{abstract}

Kata kunci : alat ortodontik cekat, status kebersihan mulut, status karies. 
Penggunaan alat ortodontik cekat saat ini sudah banyak digunakan di masyarakat luas. Orang dewasa maupun anak-anak menggunakan alat ortodontik cekat bukan hanya untuk kepentingan perawatan gigi dan mulut saja tapi juga sebagai bagian dari gaya hidup. Masyarakat sering tidak menyadari risiko dari penggunaan alat ortodontik cekat, seperti masalah kebersihan mulut dan karies. Perawatan ortodontik khususnya penggunaan alat ortodontik cekat dapat memberikan dampak berupa perubahan lingkungan rongga mulut dan komposisi flora rongga mulut, peningkatan jumlah plak yang dapat menyebabkan karies gigi, sebagai akibat sulitnya prosedur kebersihan mulut pada pasien. ${ }^{1}$

Alat ortodontik cekat memiliki desain yang lebih sulit untuk dibersihkan dibandingkan dengan alat ortodontik lepasan, sehingga pasien pengguna alat ortodontik cekat lebih sulit untuk memelihara kebersihan mulut selama perawatan. ${ }^{2}$ Perawatan ortodontik dengan komponen alat ortodontik cekat seperti penggunaan bracket dan band dapat menjadi tempat plak berakumulasi akibat meningkatnya pembentukan biofilm setelah insersi. Kontrol plak yang teratur diperlukan untuk menjaga kebersihan mulut selama perawatan ortodontik cekat. ${ }^{3}$

Kebersihan mulut yang buruk dapat menyebabkan karies pada pengguna alat ortodontik cekat. Proses bakterial pada karies secara progresif dapat menyebabkan kerusakan pada struktur jaringan keras gigi. ${ }^{4}$ Penelitian di Saudi Arabia yang dilakukan oleh Ahmed dkk pada tahun 2010 menunjukkan bahwa pasien yang sedang berada dalam perawatan ortodontik cekat dan tidak menjaga kebersihan mulutnya berisiko tinggi terkena karies. ${ }^{5}$

Penelitian yang dilakukan oleh Wirna pada tahun 2010 tentang kebersihan gigi dan mulut di Fakultas Kedokteran Gigi Universitas Sumatera Utara menunjukkan bahwa kebersihan mulut pada mahasiswa pengguna alat ortodontik cekat rata-rata termasuk pada kategori baik hingga sedang. ${ }^{6}$ Mahasiswa kedokteran gigi dianggap sudah memiliki pengetahuan tentang kebersihan gigi dan mulut serta karies, mengetahui risiko penggunaan alat ortodontik cekat, sehingga memiliki kesadaran lebih untuk menjaga kebersihan gigi dan mulutnya.

Survei awal yang dilakukan di Program Studi Kedokteran Gigi Universitas Sam Ratulangi untuk memperoleh data tentang jumlah mahasiswa sekaligus wawancara untuk memperoleh gambaran tentang penggunaan alat ortodontik cekat, menunjukkan adanya keluhan pada pasien pengguna alat ortodontik cekat. Keluhan yang muncul biasanya berkaitan dengan kesulitan dalam membersihkan sisa makanan yang tersangkut pada komponen alat ortodontik cekat seperti bracket sehingga menyebabkan penumpukan makanan dan munculnya karies pada daerah yang sulit dijangkau saat menyikat gigi.

\section{METODE PENELITIAN}

Jenis penelitian ini merupakan penelitian deskriptif. Penelitian dilaksanakan di Program Studi Kedokteran Gigi Fakultas Kedokteran Universitas Sam Ratulangi Manado pada bulan November tahun 2012. Populasi pada penelitian ini yaitu semua mahasiswa pengguna alat ortodontik cekat di Program Studi Kedokteran Gigi Fakultas Kedokteran Universitas Sam Ratulangi Manado berjumlah 38 orang. Kriteria inklusi untuk penelitian ini yaitu menggunakan alat ortodontik cekat minimal 1 bulan, bersedia menjadi subjek penelitian yang dibuktikan dengan kesediaan untuk mengisi surat persetujuan sebagai subjek penelitian dan kooperatif dalam pengambilan data. Subjek penelitian yang menggunakan alat ortodontik cekat kurang dari 1 bulan dan tidak hadir saat penelitian dilakukan dimasukkan dalam kriteria eksklusi. Metode pengambilan sampel yaitu Total Sampling.

Pengambilan data kebersihan mulut dan karies gigi pada mahasiswa dilakukan dengan cara mengumpulkan subjek penelitian di salah satu ruang kelas Program Studi Kedokteran Gigi Fakultas Kedokteran Universitas Sam Ratulangi yang kosong untuk melakukan pemeriksaan. Mahasiswa tahap pendidikan profesi diperiksa di ruangan pemeriksaan Balai Pengobatan 
Rumah Sakit Gigi dan Mulut Pendidikan (BP-RSGMP) Universitas Sam Ratulangi. Pemeriksaan dilakukan selama 10 hari pada hari yang ditentukan untuk masing-masing angkatan yang diperiksa dan setiap harinya terkumpul sekitar 6 hingga 8 mahasiswa yang diperiksa.

Pemeriksaan kebersihan mulut dilakukan dengan PHP Index dengan prosedur yaitu aplikasikan disclosing solution pada permukaan gigi yang diperiksa, yaitu terdiri dari gigi 16, 11, 26, 36, 31 dan 46. Pasien diminta untuk mendesis selama 30 detik kemudian meludah tapi tidak berkumur kemudian diperiksa dengan kaca mulut.

Permukaan gigi yang diperiksa dibagi menjadi 5 bagian yaitu secara vertikal dibagi menjadi sisi mesial, tengah dan distal, dan secara horizontal yaitu bagian tengah gigi dibagi menjadi 3 yang terdiri dari sisi lingual, tengah, dan oklusal atau 1/3 incisal (Gambar 1).

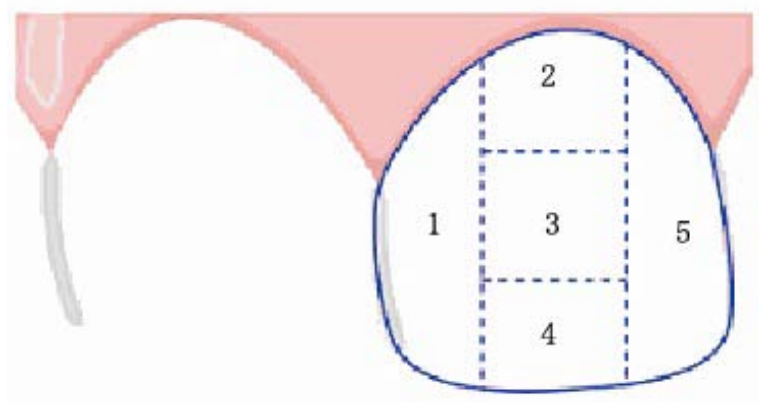

Gambar 1. Permukaan gigi yang diperiksa dibagi menjadi 5 bagian. $^{7}$

Setiap area yang terdapat plak diberi poin maka jumlah poin pada setiap gigi berkisar antara 1 sampai 5 .

Jumlah rata-rata PHP Index diperoleh dengan cara memeriksa gigi-gigi individual tersebut, melihat bagian mana yang terdapat plak, kemudian dijumlahkan dengan rumus sebagai berikut. $^{7}$

PHP Index $=\frac{\text { Jumla } h \text { plak semua gigi yang diperiksa }}{6}$
Kategori PHP Index berdasarkan jumlah rata-rata plak yang nampak pada permukaan gigi untuk menentukan kebersihan mulut dengan kategori sangat baik, baik, sedang dan buruk (Tabel 1$)^{7}$

Tabel 1. Kategori skor PHP Index. ${ }^{7}$

\begin{tabular}{cc}
\hline Skor & Kategori \\
\hline 0 & Sangat baik. \\
$0,1-1,7$ & Baik. \\
$1,8-3,4$ & Sedang. \\
$3,5-5,0$ & Buruk. \\
\hline
\end{tabular}

Karies gigi diperiksa menggunakan indeks DMF-T dengan melihat jumlah gigi karies yang masih bisa ditambal (Decay), gigi yang hilang karena karies (Missing) dan gigi yang ditambal akibat karies yang muncul selama perawatan ortodontik cekat (Filling).

Pemeriksaan DMF-T dilakukan dengan memeriksa 28 gigi yang ada. Jumlah DMF$\mathrm{T}$ rata-rata dihitung dengan cara menjumlahkan jumlah gigi yang karies, hilang dan ditambal lalu dibagi dengan jumlah populasi. ${ }^{7}$

$$
\text { Indeks DMF-T }=\frac{\mathrm{D}+\mathrm{M}+\mathrm{F}}{\text { Jumla } h \text { Populasi }}
$$

Kategori status karies berdasarkan jumlah DMF-T rata-rata menurut WHO mulai dari tingkat sangat rendah sampai sangat tinggi, dapat dilihat pada Tabel 2.

Tabel 2. Kategori DMF-T. ${ }^{8}$

\begin{tabular}{cc}
\hline Skor & Kategori \\
\hline $0,0-1,1$ & Sangat rendah \\
$1,2-2,6$ & Rendah \\
$2,7-4,4$ & Sedang \\
$4,5-6,5$ & Tinggi \\
$>6,6$ & Sangat Tinggi \\
\hline
\end{tabular}

Data yang didapat kemudian dicatat dan dimasukkan dalam tabel kerja, diolah 
4 Jurnal e-GiGi (eG), Volume 1, Nomor 1, Maret 2013, hlm. 1-7

berdasarkan distribusi frekuensi kemudian disajikan dalam bentuk diagram.

\section{HASIL PENELITIAN}

Penelitian dilaksanakan di Program Studi Kedokteran Gigi Fakultas Kedokteran Universitas Sam Ratulangi dan juga di Balai Pengobatan Rumah Sakit Gigi dan Mulut Pendidikan (BP-RSGMP) Universitas Sam Ratulangi. Subjek penelitian yang didapatkan berdasarkan kriteria inklusi berjumlah 38 orang dan distribusi berdasarkan jenis kelamin dapat dilihat pada Gambar 2.

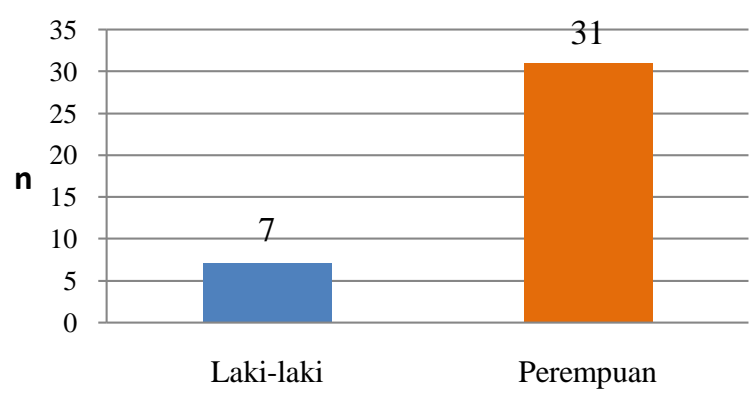

Gambar 2. Diagram distribusi subjek penelitian berdasarkan jenis kelamin.

Gambar di atas menunjukkan distribusi subjek penelitian berdasarkan jenis kelamin sebagian besar didominasi oleh mahasiswa perempuan (81,58\%) dibanding dengan mahasiswa laki-laki (18,42\%).

Hasil pemeriksaan kebersihan mulut dengan menggunakan PHP Index dari 38 mahasiswa pengguna alat ortodontik cekat dapat dibagi dalam 4 kategori yaitu sangat baik, baik, sedang, dan buruk (Gambar 3).

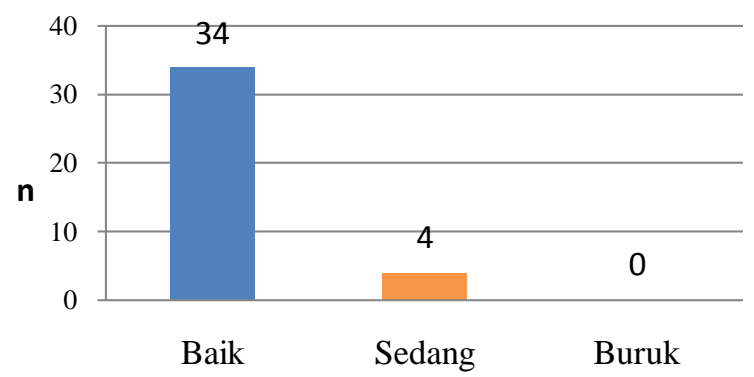

Gambar 3. Diagram distribusi kebersihan mulut (PHP).
Gambar di atas menunjukkan bahwa sebagian besar mahasiswa pengguna alat ortodontik cekat $(89,47 \%)$ memiliki kebersihan mulut yang baik, sedangkan yang tersisa memiliki kebersihan mulut sedang $(10,53 \%)$ dan tidak terdapat subjek penelitian dengan kebersihan mulut yang buruk.

Hasil pemeriksaan karies berdasarkan jumlah mahasiswa yang terpapar karies dan bebas karies dapat dilihat pada Gambar 4.

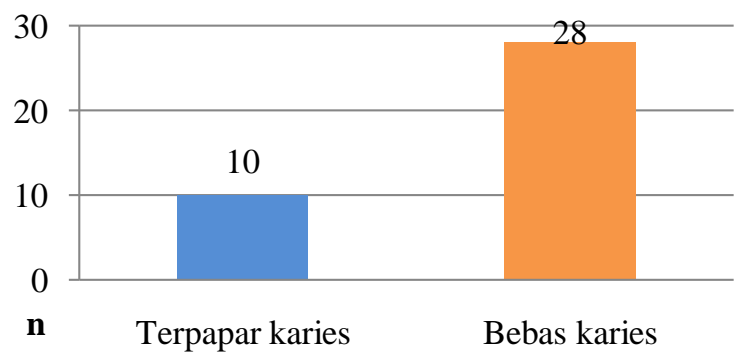

Gambar 4. Distribusi jumlah subjek penelitian yang terpapar karies dan bebas karies.

Gambar di atas menunjukkan bahwa sebagian besar mahasiswa pengguna alat ortodontik cekat $(73,69 \%)$ bebas karies sedangkan sisanya $(26,31 \%)$ terpapar karies.

Hasil pemeriksaan karies berdasarkan distribusi komponen DMF-T dapat dilihat pada diagram (Gambar 5).

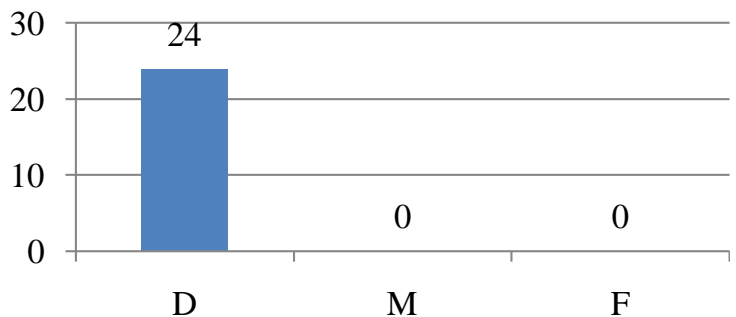

Gambar 5. Diagram distribusi komponen DMFT.

Diagram di atas menunjukkan bahwa hanya komponen D yang ditemukan pada subjek penelitian yang diperiksa, dan tidak terdapat komponen $\mathrm{M}$ dan $\mathrm{F}$.

Keadaan karies pada mahasiswa pengguna alat ortodontik cekat dapat ditentukan dari jumlah DMF-T rata-rata 
yang diperoleh melalui hasil pembagian dari jumlah ketiga komponen DMF-T di atas dan jumlah subjek penelitian. Hasil pemeriksaan status karies berdasarkan jumlah DMF-T dapat dilihat pada Gambar 6.

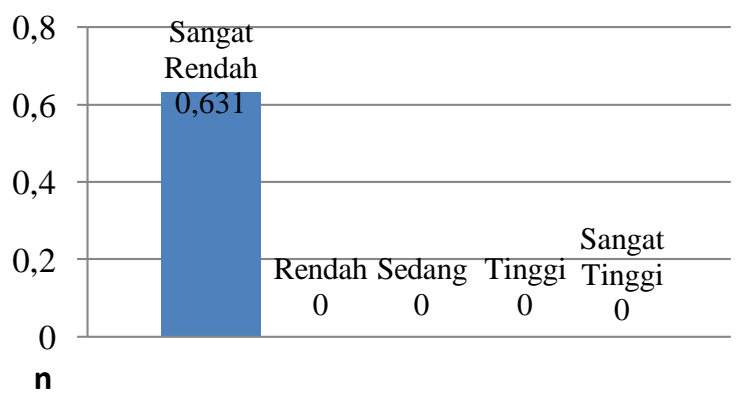

Gambar 6. Kategori status karies gigi berdasarkan indeks DMF-T.

Jumlah DMF-T rata-rata ialah 0,631 dan menurut kategori indeks DMF-T dari WHO termasuk pada kategori sangat rendah.

\section{BAHASAN}

Hasil pemeriksaan kebersihan mulut dengan menggunakan PHP Index menunjukkan bahwa sebagian besar $(89,47 \%)$ subjek penelitian yang diperiksa memiliki kebersihan mulut yang baik. Kebersihan mulut dipengaruhi oleh perilaku pemeliharaan kebersihan mulut pada masing-masing individu. Perilaku dapat dibentuk dari lingkungan dan juga dari faktor genetik. Pembentukan perilaku yang berasal dari lingkungan dapat berupa pengalaman yang diperoleh dari lingkungan kehidupan seharihari, sedangkan untuk faktor genetik berupa perilaku yang diturunkan dari orang tua. ${ }^{9}$ Peneliti berasumsi bahwa hasil penelitian ini dipengaruhi oleh perilaku kebersihan mulut mahasiswa Kedokteran Gigi. Pengetahuan yang diperoleh melalui proses belajar dapat juga memengaruhi pembentukan perilaku. Mahasiswa kedokteran gigi yang telah memiliki pengetahuan tentang kebersihan gigi dan mulut dapat menuangkan pengetahuan yang diperoleh sehingga dapat menghasilkan perubahan sikap dan diwujudkan dalam tindakan pemeliharaan kebersihan mulutnya sendiri. Asumsi tersebut ditunjang oleh penelitian yang dilakukan Wirna tahun 2010 pada mahasiswa pengguna alat ortodontik cekat di Fakultas Kedokteran Gigi Universitas Sumatera Utara. Hasil penelitian yang diperoleh menunjukkan bahwa mahasiswa yang menjadi subjek penelitian memiliki kebersihan mulut pada kategori baik hingga sedang. ${ }^{6}$ Penelitian ini juga sejalan dengan penelitian yang dilakukan oleh Nor tahun 2011 pada mahasiswa Fakultas Kedokteran Gigi Universitas Airlangga yang menunjukkan bahwa mahasiswa kedokteran gigi yang menjadi subjek penelitian memiliki perilaku memelihara kebersihan mulut yang lebih baik daripada mahasiswa pada jurusan lain. ${ }^{10}$

Kebersihan mulut yang baik juga dipengaruhi oleh peran dokter gigi dalam memberikan motivasi dan intruksi selama perawatan ortodontik cekat. Dokter gigi perlu memberikan motivasi dan intruksi yang benar sejak awal sampai akhir perawatan ortodontik cekat, sehingga pasien bisa lebih peduli pada kebersihan mulutnya. Hal ini juga dipaparkan oleh Wulandari dalam penelitiannya pada tahun 2012 di Rumah Sakit Gigi dan Mulut Universitas Indonesia. Dorongan motivasi yang diberikan dokter gigi pada pengguna alat ortodontik cekat menyebabkan terjadinya penurunan jumlah plak pada pasien yang menjalani perawatan ortodontik cekat. ${ }^{11}$ Namun dalam penelitian ini faktor motivasi kepada pasien itu sendiri tidak diteliti.

Hasil pemeriksaan status karies pada 38 mahasiswa yang menjadi subjek penelitian ditemukan 10 di antaranya terpapar karies. Karies yang ditemukan rata-rata dimiliki oleh mahasiswa yang sudah menjalani perawatan lebih dari satu tahun. Peneliti berasumsi bahwa penyebab munculnya karies dipengaruhi oleh perilaku menjaga kebersihan gigi dan mulut mahasiswa pengguna alat ortodontik cekat. Permukaan gigi yang tidak disikat dengan benar dapat menyebabkan penumpukan makanan di sekitar komponen alat ortodontik cekat dan memicu terjadinya pembentukan plak. Penggunan alat ortodontik cekat itu sendiri sudah menjadi faktor risiko pembentukan 
karies. Apabila perilaku kebersihan mulut tersebut tidak diubah, maka lama-kelamaan proses pembentukan karies bisa terjadi. Hasil penelitian ini sejalan dengan penelitian yang dilakukan Ahmed pada pengguna alat ortodontik cekat di Pakistan pada tahun 2010 yang menunjukkan bahwa prevalensi karies menjadi lebih tinggi setelah 1 tahun penggunaan alat ortodontik cekat. ${ }^{4}$

Pada pemeriksaan DMF-T ditemukan hanya komponen D saja atau gigi yang mengalami karies. Karies yang muncul sebagian besar merupakan karies pada permukaan saja dan hanya terdapat pada gigi geraham. Hal ini disebabkan karena pada gigi geraham, komponen alat ortodontik cekat yaitu band menutupi 3/4 permukaan gigi geraham. Hal ini mempersulit pasien dalam membersihkan permukaan gigi tersebut, sehingga memudahkan terjadinya pembentukan karies.

Alasan lain yang dapat menyebabkan pembentukan karies yaitu kelalaian mahasiswa pengguna alat ortodontik cekat dalam melakukan kontrol ke dokter gigi. Kontrol rutin untuk memeriksa kebersihan mulut pada pengguna alat ortodontik cekat sebaiknya dilakukan 3 bulan sekali, berbeda dengan individu yang tidak menggunakan alat ortodontik cekat yang disarankan melakukan kontrol setiap 6 bulan sekali. Penggunaan alat ortodontik cekat dapat merupakan salah satu faktor risiko terjadinya karies gigi pada penggunanya. Jangka waktu kontrol yang terlalu lama dapat menyebabkan lesi karies yang mungkin terbentuk akibat kebersihan gigi dan mulut yang kurang baik menjadi terlambat dideteksi sehingga bisa berkembang menjadi lebih parah.

Jumlah DMF-T rata-rata pada subjek penelitian yang diperiksa yaitu 0,631. Berdasarkan penilaian kategori WHO termasuk pada kategori sangat rendah, yang menggambarkan sangat rendahnya status karies mahasiswa Program Studi Kedokteran Gigi Universitas Sam Ratulangi pengguna alat ortodontik cekat. Peneliti berasumsi bahwa hal ini mungkin disebabkan oleh karena mahasiswa sudah memiliki perilaku yang baik dalam pemeliharaan kebersihan mulut. Selain itu, tindakan pembersihan gigi dari karies yang dilakukan pada awal perawatan ortodontik juga dapat menyebabkan rendahnya status karies mahasiswa terutama pada pasien yang belum lama menggunakan alat ortodontik cekat. Namun hal ini juga dikembalikan lagi pada perilaku mahasiswa dalam memelihara kebersihan mulut, yang ditunjang oleh intruksi dari dokter gigi di awal perawatan ortodontik cekat dalam mengarahkan pasien untuk menjaga kebersihan mulutnya dan rutin melakukan kontrol selama perawatan. Pengetahuan yang diperoleh mahasiswa saat menjalani pendidikan di Program Studi Kedokteran Gigi juga dapat menambah pengetahuan mahasiswa sehingga lebih menjaga kebersihan gigi dan mulut terutama saat menjalani perawatan ortodontik cekat sehingga dapat terhindar dari karies.

\section{SIMPULAN DAN SARAN}

Penelitian ini menunjukkan bahwa status kebersihan mulut mahasiswa pengguna alat ortodontik cekat termasuk pada kategori baik (89,47\%). Status karies mahasiswa pengguna alat ortodontik cekat termasuk pada kategori sangat rendah $(0,631)$ di mana hanya terdapat 10 mahasiswa (26,31\%) yang terpapar karies.

Masyarakat yang menggunakan alat ortodontik cekat perlu memiliki kepedulian dalam memelihara kebersihan gigi dan mulutnya agar terhindar dari karies. Untuk menunjang pengetahuan masyarakat maka perlu dilakukan upaya penyuluhan dalam rangka meningkatkan pengetahuan masyarakat tentang kebersihan mulut, terlebih khusus pada masyarakat pengguna alat ortodontik cekat di luar populasi mahasiswa Kedokteran Gigi; sehingga dapat meningkatkan pengetahuan masyarakat dan mencegah terjadinya karies dan penyakit periodontal lainnya. Penelitian sejenis dengan melibatkan populasi yang lebih besar juga perlu dilakukan, yaitu dengan melibatkan mahasiswa Kedokteran Gigi pengguna alat ortodontik cekat serta pada masyarakat non mahasiswa Kedokteran 
Gigi, sehingga dapat diperoleh hasil penelitian yang lebih valid. Pembatasan subjek penelitian berdasarkan lamanya perawatan ortodontik cekat serta penelitian yang mencakup perilaku pengguna alat ortodontik cekat dalam pemeliharaan kebersihan mulut juga perlu dilakukan.

\section{UCAPAN TERIMA KASIH}

Penulis mengucapkan terima kasih kepada drg. Ni Wayan Mariati, MKes (Dosen penguji I) dan drg. Bernat S. P. Hutagalung, MKes (Dosen penguji II) atas masukan yang telah diberikan kepada penulis. Penulis juga mengucapkan terima kasih kepada semua pihak yang telah membantu penulis dalam menemukan ide dalam penulisan karya tulis ini.

\section{DAFTAR PUSTAKA}

1. Ay ZY, Sayin MO, Ozat Y, Goster T, Atilla AO, Bozkurt FY. Appropriate oral hygiene motivation method for patients with fixed appliances. Angle Orthodontist. 2007; 77(6):1085-89.

2. Singh G. Fixed orthodontic appliances. In: Singh G, editor. Text Book of Orthodontics (Second Edition). New Delhi: Jaypee Publishers, 2007; p.449.

3. Al-Anezi SA, Harradine NWT. Quantifying plaque during orthodontic treatment. Angle
Orthodontist. 2012;82:748-53.

4. Ahmed I, Haque SU, Nazir R. Carious lesions in patients undergoing orthodontic treatment. J Pak Med Assoc. 2011;61(12):116-7.

5. Anas H, Al M. Saad AK, Heidrun K, Dowen B. Caries risk profiles in orthodontic patients at follow-up using cariogram. Angle Orthodontist. 2009;79(2):323-30.

6. Sukmawaty W. Efektifitas sikat gigi konvensional dan sikat gigi khusus ortodonti terhadap penurunan indeks plak pemakai fixed orthodontic pada mahasiswa FKG USU [Skripsi]. Medan: Kedokteran Gigi USU; 2002; p.27.

7. Marya CM. Dental Indices. In: Marya CM, editor. A Textbook of Public Health Dentistry. New Delhi: Jaypee Publishers, 2011; p.192-3, 204-5.

8. World Health Organization. DMFT Levels at 12 Years. United States: Univertsity of Michigan; p.1.

9. Herijulianti E, Tati SI, Sri A. Pendidikan Kesehatan Gigi. Jakarta: Penerbit Buku Kedokteran EGC, 2001; p.35.

10. Abdullah BTAN. Perilaku menjaga kebersihan rongga mulut pada mahasiswa Fakultas Kedokteran Gigi Universitas Airlangga Surabaya [Skripsi] Surabaya: UNAIR; 2011; p.iv.

11. Wulandari NNS. Pengaruh berbagai metode motivasi pada skor oral hygiene pasien ortodonti cekat di RSGM-P FKG UI [Tesis]. Jakarta: FKGUI; 2012; p.42-6. 